\title{
Prolactin inhibition at the end of lactation programs for a central hypothyroidism in adult rat
}

\author{
Isabela Teixeira Bonomo ${ }^{1}$, Patrícia Cristina Lisboa ${ }^{1}$, Magna Cottini Fonseca Passos ${ }^{2}$, Simone \\ Bezerra Alves $^{1}$, Adelina Martha Reis ${ }^{3}$ and Egberto Gaspar de Moura ${ }^{1}$ \\ ${ }^{1}$ Departamento de Ciências Fisiológicas - 50 andar, Instituto de Biologia Roberto Alcântara Gomes and ${ }^{2}$ Departamento de Nutrição Aplicada, Instituto de \\ Nutrição, Universidade do Estado do Rio de Janeiro, Avenida 28 de setembro, 87, Rio de Janeiro, RJ 20551-030, Brazil \\ ${ }^{3}$ Departamento de Fisiologia e Biofísica, ICB, Universidade Federal de Minas Gerais, Belo Horizonte, MG, Brazil \\ (Correspondence should be addressed to E G de Moura; Email: egberto@pq.cnpq.br)
}

\begin{abstract}
Malnutrition during lactation is associated with hypoprolactinemia and failure in milk production. Adult rats whose mothers were malnourished presented higher body weight and serum triiodothyronine $\left(\mathrm{T}_{3}\right)$. Maternal hypoprolactinemia at the end of lactation caused higher body weight in adult life, suggesting an association between maternal prolactin (PRL) level and programming of the offspring's adult body weight. Here, we studied the consequences of the maternal PRL inhibition at the end of lactation by bromocriptine (BRO) injection, a dopaminergic agonist, upon serum TSH and thyroid hormones, thyroid iodide uptake, liver mitochondrial $\alpha$-glycerophosphate dehydrogenase (mGPD), liver and pituitary de-iodinase activities (D1 and/or D2), and in vitro post-TRH TSH release in the adult offspring. Wistar lactating rats were divided into $\mathrm{BRO}$ - injected with $1 \mathrm{mg} /$ twice a day, daily for the last 3 days of lactation, and
\end{abstract}

$\mathrm{C}-$ control, saline-injected with the same frequency. At 180 days of age, the offspring were injected with ${ }^{125} \mathrm{I}$ i.p. and after $2 \mathrm{~h}$, they were killed. Adult animals whose mothers were treated with $\mathrm{BRO}$ at the end of lactation presented lower serum $\mathrm{TSH}(-51 \%), \mathrm{T}_{3}(-23 \%)$, and thyroxine $(-21 \%)$, lower thyroid ${ }^{125} \mathrm{I}$ uptake $(-41 \%)$, liver $\operatorname{mGPD}(-55 \%)$, and pituitary D2 $(-51 \%)$ activities, without changes in the in vitro post-TRH TSH release. We show that maternal PRL suppression at the end of lactation programs a hypometabolic state in adulthood, in part due to a thyroid hypofunction, caused by a central hypothyroidism, probably due to decreased TRH secretion. We suggest that PRL during lactation can regulate the hypothalamus-pituitary-thyroid axis and programs its function. Journal of Endocrinology (2008) 198, 331-337

\section{Introduction}

Some studies have shown that adverse situations that affect the development in critical periods of life, such as undernutrition or hormonal changes, would be able to influence the structure and physiology of organs and tissues in a permanent way (Walker \& Courtin 1985, Pracyk et al. 1992, Dorner \& Plagemann 1994, de Moura \& Passos 2005). This biological phenomenon that establishes the relationship between these stimuli in critical periods of life, such as gestation and lactation, and future functional state is called programming (Lucas 1994, Barker 2004, de Moura \& Passos 2005).

Lactation is a critical period because in this phase important cognitive and neurological development occurs, which suggests that adverse environmental changes can cause physiological modifications that are able to predispose the development of some diseases in adulthood (de Moura \& Passos 2005, Miñana-Solis \& Escobar 2006).

We evidenced that adverse situations early in life, such as malnutrition (Passos et al. 2002, Teixeira et al. 2002, Dutra et al. 2003, Passos et al. 2004, Vicente et al. 2004, Fagundes et al. 2007, de Moura et al. 2007) and hormonal (de Oliveira Cravo et al. 2002, Teixeira et al. 2003, Lins et al. 2005, Toste et al. 2006a,b, Bonomo et al. 2007, Passos et al. 2007) changes during lactation, could permanently affect the progeny. Maternal energy malnutrition during lactation programs for a higher body weight in adulthood; however, protein malnutrition programs for a lower body weight in the adult offspring (Passos et al. 2000, Teixeira et al. 2002).

We have suggested a relationship between neonatal nutritional status and thyroid function in adult life, because we have demonstrated that maternal protein malnutrition during lactation programs for a hyperthyroidism at adulthood in rodents (Passos et al. 2002, Dutra et al. 2003, Lisboa et al. 2008). Recently, it was reported that women with low birth weight had a higher prevalence of hypothyroidism in adulthood (Kajantie et al. 2006). In addition, according to Radetti et al. (2006), prematures, independent of their birth weight or length, presented a higher prevalence of disturbance on the hypothalamus-pituitary-thyroid axis later in life.

Maternal malnutrition during lactation is associated with a failure in milk production (Passos et al. 2000) in rats, caused by 
hypoprolactinemia (Lisboa et al. 2006). The bromocriptine (BRO) administration to lactating dams at the end of lactation caused milk production inhibition and neonatal malnutrition, evidenced by the lower body weight of their pups at weaning and important changes in the leptin transfer through the milk and pups' leptinemia (Bonomo et al. 2005) that reproduces the leptinemia of the offspring from malnourished dams (Teixeira et al. 2002). We also detected that, in adult life, offspring from BRO-treated mothers developed obesity without hyperphagia, suggesting a hypometabolic state, characterized by higher body weight, higher central and total body fat mass, hyperleptinemia and central resistance to the anorectic effect of leptin (Bonomo et al. 2007). Also, leptin administration during lactation to the mothers (Passos et al. 2007) or to the pups (Teixeira et al. 2003, Toste et al. 2006a) programs for higher serum tri-iodothyronine $\left(T_{3}\right)$.

So, the present study was designed to evaluate the later repercussion of maternal hypoprolactinemia upon the programming of the thyroid function in the adult offspring.

\section{Materials and Methods}

Three-month-old Wistar rats were maintained in a room under a darkness-light cycle (0700-1900 h) and controlled temperature $\left(25 \pm 1{ }^{\circ} \mathrm{C}\right)$. Virgin female rats were caged with one male rat at a proportion of 2:1. After mating, each female was placed in an individual cage with water and food made available ad libitum until parturition. The use of the animals was according to the Animal Care and Use Committee of the Biology Institute of the State University of Rio de Janeiro (CEA/186/2007), which based their analysis on the principles described in the Guide for the Care and Use of Laboratory Animals (Bayne 1996).

\section{Experimental model of maternal hypoprolactinemia during lactation}

After birth, excess pups were removed, so that only six male pups were kept per dam, because it has been shown that this procedure maximizes lactation performance (Fischbeck \& Rasmussen 1987).

Lactating rats were separated into the following groups: $\mathrm{BRO}$ - treated with $1 \mathrm{mg}$ bromo- $\alpha$-ergocriptine s.c. (BRO Novartis, São Paulo, Brazil), twice a day, for 3 days at the end of lactation, and $\mathrm{C}-$ control group, which received saline for the same time. We used six lactating rats per group and two pups of each dam were randomly separated ( $n=12$ pups).

On day 21 of lactation, dams' serum prolactin (PRL) levels were measured by specific RIA using reagents supplied by the National Institute of Diabetes and Digestive and Kidney Diseases (NIDDKD, NIH, Bethesda, MD, USA). Data are reported in $\mathrm{ng} / \mathrm{ml}$ from the reference preparation, RP-3. Samples were analyzed in a single assay and the intra-assay coefficient was $8 \%$. In addition, we performed an estimate of milk production as described previously (Passos et al. 2000, Bonomo et al. 2005).
Maternal food intake was measured. We also followed the body weight of mothers and pups during lactation.

After weaning, body weight and food intake were monitored every 4 days until 180 days. At 180 days, in order to determine the thyroid's $2 \mathrm{~h}$ radioiodine uptake, the offspring received a single i.p. injection containing $2 \cdot 22 \times 10^{4}$ $\mathrm{Bq}$ of ${ }^{125} \mathrm{I}$ (CNEN, Rio de Janeiro, Brazil). After 2 h, animals were killed by decapitation to collect blood, thyroid, pituitary, and liver.

\section{Thyrotropin (TSH), $T_{3}$, and $T_{4}$ serum concentrations}

TSH was measured by specific RIA, using a kit for rat TSH supplied by the NIDDKD (NIH) and data were expressed in terms of the reference preparation provided (RP-3). The intra-assay variation coefficient was $7 \cdot 1 \%$, with $0.09 \mathrm{ng} / \mathrm{ml}$ as the lower limit of detection.

Total serum $\mathrm{T}_{3}\left(\mathrm{TT}_{3}\right)$ and thyroxine $\left(\mathrm{TT}_{4}\right)$ were determined by RIA, using commercial kits (ICN pharmaceuticals, Inc., Costa Mesa, CA, USA), in which we used control standard curves diluted in iodothyronine-free rat serum (charcoal treated). The intra-assay variation coefficient for $\mathrm{T}_{4}$ was $5 \cdot 7 \%$, with $2 \mu \mathrm{g} / \mathrm{dl}$ as the lower limit of detection, and for $\mathrm{T}_{3}$ the values were $5.6 \%$ and $25 \mathrm{ng} / \mathrm{dl}$ respectively.

\section{Mitochondrial GPD activity}

The liver $\boldsymbol{\alpha}$-glycerol-3-phosphate dehydrogenase activity (GPD) was measured in the mitochondrial fraction using phenazine methosulfate (PMS) as an electron transporter between the reduced enzyme and iodonitrotetrazolium chloride violet (INT) (Bernal et al. 1978, Oliveira et al. 2007). The assay was performed in the presence of $0.1 \mathrm{M} \mathrm{DL}-\alpha-$ glycerophosphate diluted in potassium cyanide (KCN)/ potassium phosphate buffer (KPB) and a solution of $7.9 \mathrm{mM}$ INT- $0 \cdot 12 \mathrm{mM}$ PMS. Samples were analyzed at $500 \mathrm{~nm}$ and the values were expressed as absorbance (O.D)/mg of mitochondrial protein. Protein was measured using the method described by Bradford (1976).

\section{Iodothyronine de-iodinase activity}

Type 1 (D1) and 2 (D2) de-iodinase activities were measured based on methods described previously (Dutra et al. 2003, Lisboa et al. 2003a) by the release of ${ }^{125} \mathrm{I}$ from ${ }^{125} \mathrm{I}$-reverse $\mathrm{T}_{3}$ in the liver microsomes and the pituitary total homogenate. Assays were performed in phosphate buffer containing $1 \mathrm{mM}$ EDTA $(\mathrm{pH}$ 6.9). $\mathrm{D} 1$ assay was performed in the presence of $\mathrm{r}_{3}(1.5 \mu \mathrm{M}$ for the liver and $2 \mathrm{nM}$ for the pituitary), dithiothreitol (DTT) $(10 \mathrm{mM})$, and $\mathrm{T}_{4}(100 \mathrm{nM}$, only for pituitary $\mathrm{D} 2$ inhibition). D2 assay was performed with $2 \mathrm{nM} \mathrm{rT}_{3}, 10 \mathrm{mM}$ DTT, and 1 mM 6-n-propyl-2-thiouracil (PTU) (to inhibit pituitary D1). Equal aliquots of ${ }^{125} \mathrm{I}_{-} \mathrm{rT}_{3}(1.07 \mathrm{mCi} / \mu \mathrm{g}$ - New England Nuclear-Dupont, Boston, MA, USA), purified by paper electrophoresis were placed to each assay tube. Reaction was started by sample addition with the following amount of protein: 
$70-150 \mu \mathrm{g}$ for the pituitaries and $12-20 \mu \mathrm{g}$ for the liver. A blank tube was run in parallel with each assay, containing $50 \mu \mathrm{l}$ of the substrate solution and $50 \mu \mathrm{l}$ buffer, which had its values subtracted from enzyme samples. Reactions were performed on a shaking-bath at $37^{\circ} \mathrm{C}$, and stopped after 30 (liver D1) or 60 (pituitary D1 and D2) minutes by the addition of a mixture of $8 \%$ BSA and $10 \mathrm{mM}$ PTU, followed by $20 \%$ cold trichloroacetic acid. Samples were centrifuged $\left(1500 \mathrm{~g}, 4^{\circ} \mathrm{C}, 5 \mathrm{~min}\right)$ and $200 \mu \mathrm{l}$ of the supernatants were applied to Dowex $50 \mathrm{~W}-\mathrm{X} 2$ columns (100-200 mesh hydrogen form Bio-Rad). Free ${ }^{125}$ I, eluted from the column with $10 \%$ acetic acid, was measured in a $\gamma$-counter. De-iodination percentual in the presence of the enzyme was around $10-20 \%$. The amount of free ${ }^{125} \mathrm{I}$ in blank was generally less than $1-2 \%$ of the total radioactivity in the reaction mixture. The specific enzyme activity was expressed by nanomoles or fentomoles of $\mathrm{rT}_{3}$ de-iodinated/h $\mathrm{mg}$ of protein. Protein was measured by the method described by Bradford (1976).

\section{In vitro TRH-stimulated TSH release}

Pituitaries of C and BRO groups were quickly dissected out. The anterior pituitary was separated from the posterior pituitary and transected with a longitudinal midline cut. Each anterior hemipituitary was transferred to a tube containing $1 \mathrm{ml} \mathrm{Krebs-}$ Ringer-bicarbonate medium ( $\mathrm{pH} 7 \cdot 4)$ and incubated at $37{ }^{\circ} \mathrm{C}$ in an atmosphere of $95 \% \mathrm{O}_{2}-5 \% \mathrm{CO}_{2}$ in a Dubnoff metabolic shaker $(50$ cycles $/ \mathrm{min}$ ). After preincubation $(20 \mathrm{~min})$, the medium was removed and hemipituitaries were resuspended in $1 \mathrm{ml}$ fresh medium. After 1-h incubation, an aliquot was removed for measurement of basal TSH, and thyrotropinreleasing hormone (TRH) (Sigma) was added at final concentration of $50 \mathrm{nM}$. Then, glands were incubated for $30 \mathrm{~min}$ to determine the TSH release in response to TRH. Each hemipituitary was homogenized in phosphate buffer saline $(\mathrm{pH}$ 7•6) for measurement of intra-pituitary TSH content (Rettori et al. 1992, Moreira et al. 1997, Moura et al. 2001, Veiga et al. 2004, Lisboa et al. 2008). Protein content was measured by the Bradford method (Bradford 1976). The medium and pituitary TSH levels were measured by specific RIA.

\section{Statistical analysis}

Data are represented as mean \pm s.E.M. Body weight and food intake evolutions were analyzed by two-way ANOVA

Table 1 Prolactin (PRL) concentrations at weaning. Values are given as the mean \pm S.E.M.

\begin{tabular}{llll} 
& \multicolumn{1}{c}{ C } & & BRO \\
Dam's serum PRL $(\mathrm{ng} / \mathrm{ml})$ & $14 \cdot 6 \pm 6 \cdot 5$ & & $0 \cdot 5 \pm 0 \cdot 2^{*}$ \\
Milk PRL $(\mathrm{ng} / \mathrm{ml})$ & $104 \cdot 1 \pm 41 \cdot 6$ & & $97 \cdot 2 \pm 34 \cdot 7$ \\
Pup's serum PRL (ng/ml) & $2 \cdot 8 \pm 0 \cdot 5$ & & $2 \cdot 7 \pm 0 \cdot 7$ \\
\cline { 2 - 3 } & & \\
\hline
\end{tabular}

$* P<0 \cdot 05 . n=6$ mothers and 12 pups/group.
Table 2 Food intake and body weight at weaning. Values are given as the mean \pm S.E.M.

\begin{tabular}{llll} 
& C & & BRO \\
Dam's food intake $(g)$ & $45 \cdot 3 \pm 2 \cdot 9$ & & $40 \cdot 9 \pm 2 \cdot 3$ \\
Dam's body weight $(g)$ & $248 \cdot 0 \pm 7 \cdot 1$ & & $222 \cdot 0 \pm 2 \cdot 4^{*}$ \\
Pup's body weight $(g)$ & $55 \cdot 5 \pm 1 \cdot 3$ & & $51 \cdot 2 \pm 0 \cdot 6^{*}$ \\
\cline { 2 - 3 } & &
\end{tabular}

$* P<0 \cdot 05 . n=6$ mothers and 12 pups/group.

followed by Newman-Keuls multiple comparison tests. The statistical significance of TSH and thyroid iodide uptake were determined by the Mann-Whitney test and the other experimental observations by the Student's unpaired $t$-test, with significance level set at $P<0 \cdot 05$.

\section{Results}

As expected, BRO-treated mothers showed lower serum PRL at the end of lactation (day 21: $-96 \%, P<0 \cdot 01$ ), which caused a significant failure in milk production (Table 1). However, milk PRL of BRO dams and serum PRL of the BRO pups were not altered (Table 1). At weaning (Table 2), BRO dams showed lower food ingestion $(-25 \%)$ and both mothers and pups presented lower body weight $(-10$ and $-7 \%$ respectively, $P<0 \cdot 01)$.

Table 3 shows that 180-day-old animals' mothers that received $\mathrm{BRO}$ at the end of lactation presented higher total body weight $(10 \%, P<0 \cdot 05)$ without changes in the food intake ( $\mathrm{g} /$ day), corroborating our previous study (Bonomo et al. 2007).

These animals presented lower serum TSH $(-51 \%$, $P<0 \cdot 001$, Fig. 1), lower thyroid ${ }^{125}$ I uptake $(-41 \%, P<0 \cdot 05$, Fig. 2), and lower total serum thyroid hormone levels $\left(\mathrm{T}_{3}:-23 \%\right.$; $P<0 \cdot 05$, Fig. 3A and $\mathrm{T}_{4}:-21 \% ; P<0 \cdot 05$, Fig. 3B). Liver mitochondrial GPD (mGPD) activity, which is a $\mathrm{T}_{3}$-dependent enzyme, was also lower ( $-55 \%, P<0 \cdot 05$, Fig. 4$)$.

Pituitary and liver D1 activity was not affected (Fig. $5 \mathrm{a}$ and $\mathrm{b}$ respectively) in adult animals whose mothers were $\mathrm{BRO}$ treated; however, pituitary D2 activity was lower in BRO group $(-51 \%, P<0 \cdot 05$, Fig. 5 c). The in vitro TSH release after TRH stimulation was similar in both groups (Fig. 6).

Table 3 Body weight and food intake of 180-day-old rats' bromocriptine (BRO) and $\mathrm{C}$ offspring. Values are given as the mean \pm s.E.M.

\begin{tabular}{|c|c|c|}
\hline & C & BRO \\
\hline Body weight (g) & $397 \cdot 4 \pm 8 \cdot 7$ & $438 \cdot 2 \pm 20 \cdot 8^{*}$ \\
\hline Food intake (g) & $17 \cdot 2 \pm 0 \cdot 3$ & $17 \cdot 5 \pm 0 \cdot 7$ \\
\hline
\end{tabular}

$* P<0 \cdot 05 . n=12$ animals/group. 


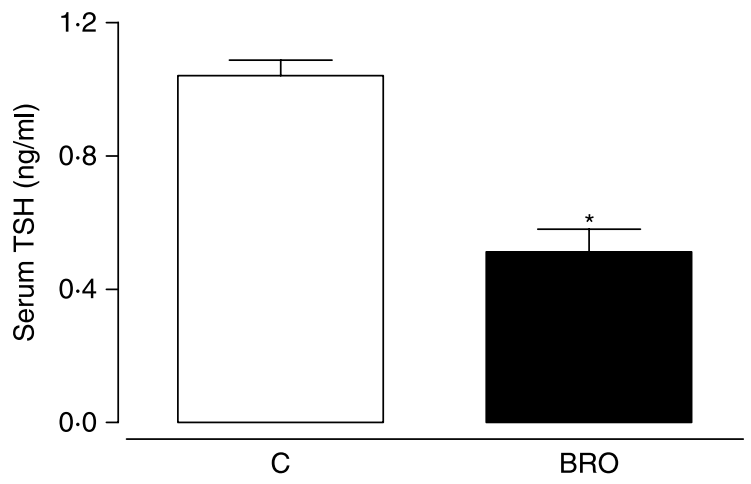

Figure 1 Serum TSH concentrations of 180-day-old rats whose dams were BRO treated (black bars) or saline treated (white bars) during 3 days of lactation. Values are given as the mean \pm s.E.M.; $* P<0 \cdot 05 ; n=12$ animals/group.

\section{Discussion}

We showed that the maternal blockage of serum PRL concentration with BRO, a specific dopamine D2 agonist, caused a calorie restriction to the offspring, since milk production was suppressed. The lower body weight in the BRO-treated mothers reinforces the concept that PRL may play a stimulatory effect on body weight gain during lactation (Fleming 1976). Thus, the BRO treatment was useful not only to address the importance of PRL, but also serves as an experimental model for energy restriction, since both mothers and pups showed a lower body weight at weaning.

Present data from animals whose mothers were BRO treated at the end of lactation reinforces our previous study of higher body weight, increase in total body fat mass, and normal food intake (Bonomo et al. 2007), suggesting a hypometabolic state. It is well documented that thyroid hormones exert important role in thermogenesis and basal metabolic rate (Silva 2006), so this hypometabolic state can be related to the lower serum thyroid hormone levels found in these programmed animals.

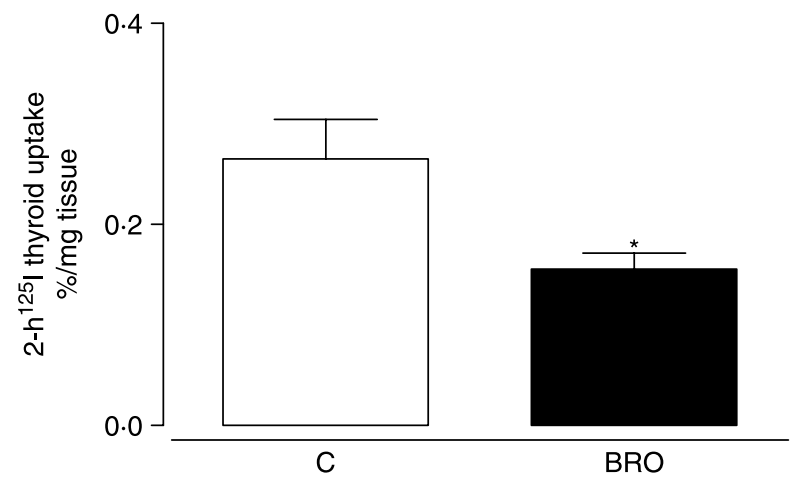

Figure 2 Thyroid ${ }^{125}$ I uptake of 180-day-old rats whose dams were BRO treated (black bars) or saline treated (white bars) during 3 days of lactation. Values are given as the mean \pm S.E.M.; ${ }^{*} P<0 \cdot 05 ; n=12$ animals/group.
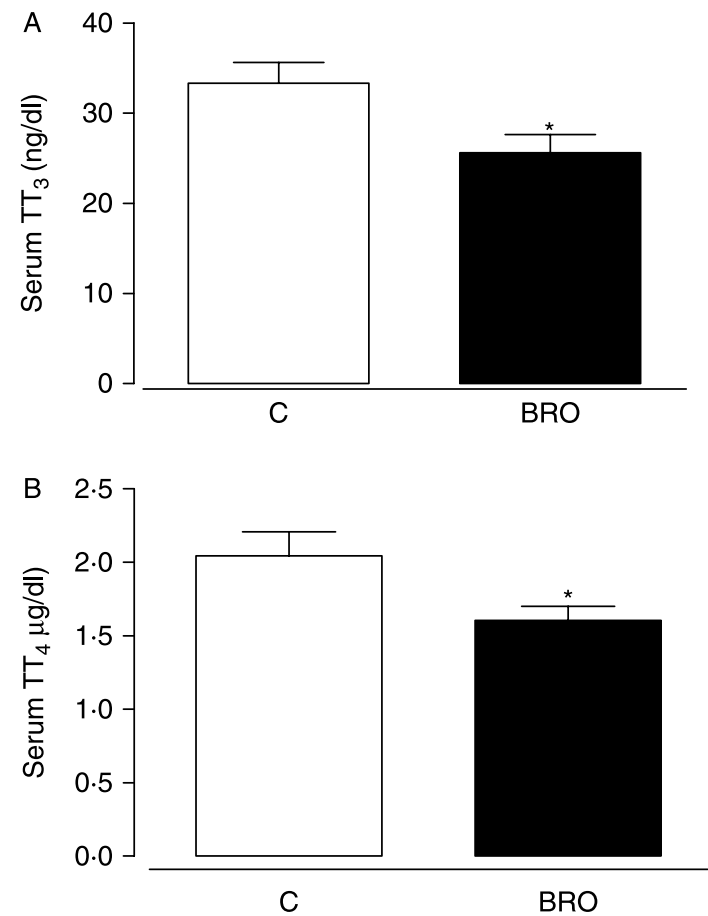

Figure 3 Total (A) serum $T_{3}$ and (B) $T_{4}$ of 180-day-old rats whose dams were BRO treated (black bars) or saline treated (white bars) during 3 days of lactation. Values are given as the mean \pm s.E.M.; ${ }^{*} P<0 \cdot 05 ; n=12$ animals/group.

The lower serum thyroid hormone concentrations presented by adult BRO animals can be explained by the lower $\mathrm{TSH}$ concentration. As it was already demonstrated that leptin stimulates TRH and TSH production and secretion (Legradi et al. 1997, Seoane et al. 2000, Ortiga-Carvalho et al. 2002), it is possible that the decrease in serum TSH could be secondary to a hypothalamic leptin resistance. The adult offspring whose mothers were $\mathrm{BRO}$ treated at the end of lactation presented a central leptin resistance (Bonomo et al. 2007), characterized by a lack of leptin's anorexigenic effect.

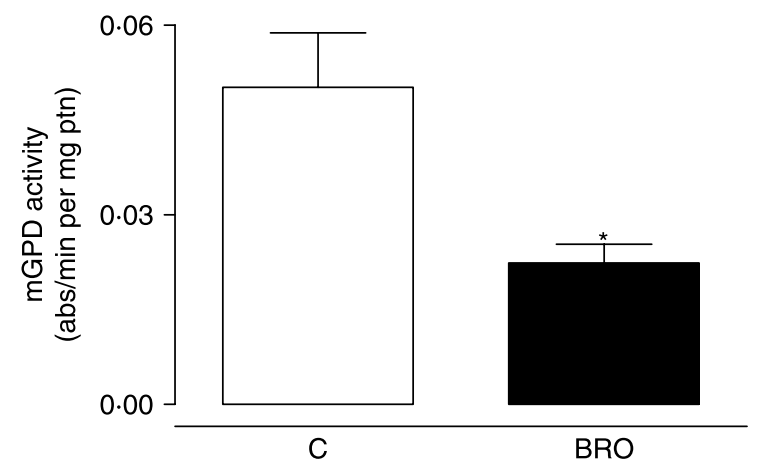

Figure 4 Liver mGPD activity of 180-day-old rats whose dams were $\mathrm{BRO}$ treated (black bars) or saline treated (white bars) during 3 days of lactation. Values are given as the mean \pm S.E.M.; ${ }^{*} P<0 \cdot 05 ; n=12$ animals/group. 

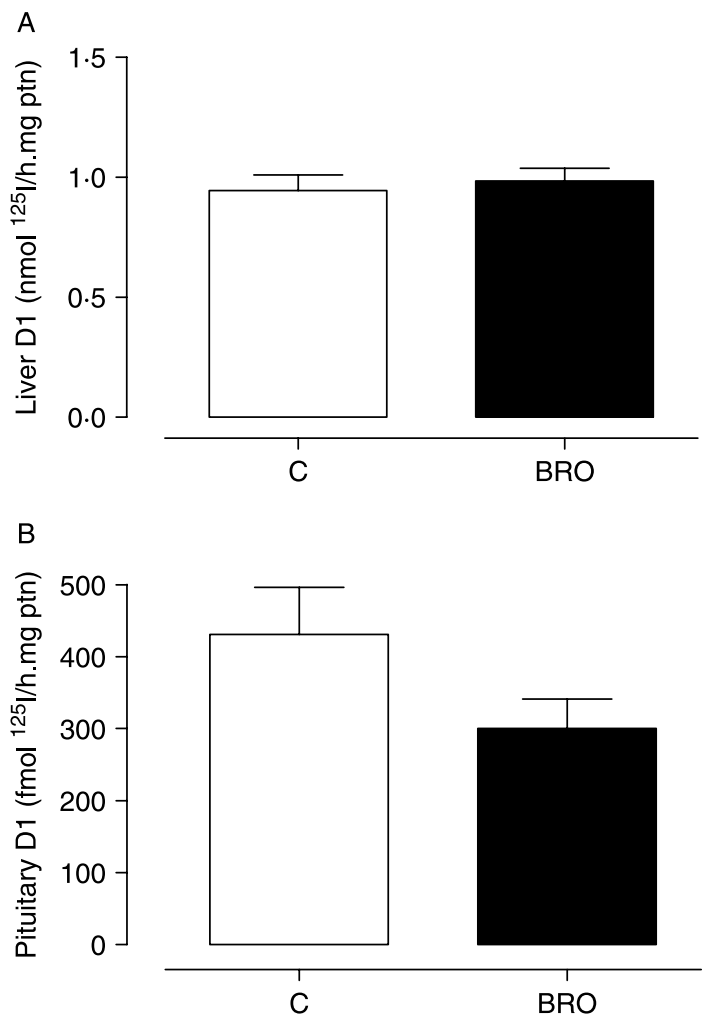

(c)

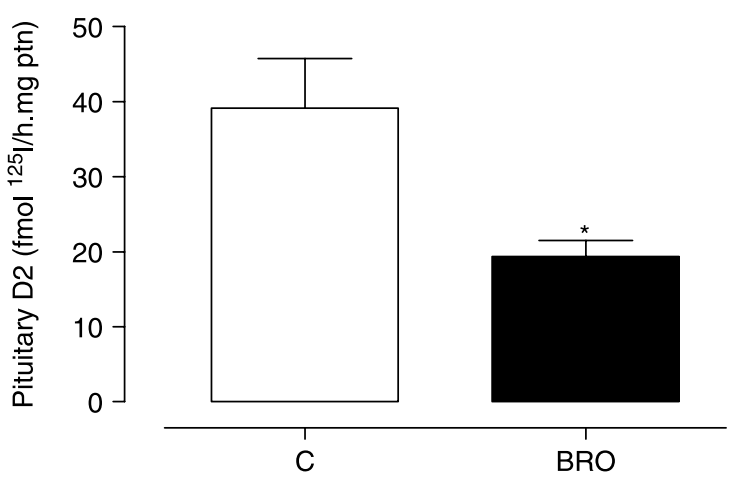

Figure 5 (A) Liver D1, (B) pituitary D1 and (C) pituitary D2 activities of 180-day-old rats whose dams were BRO treated (black bars) or saline treated (white bars) during 3 days of lactation. Values are given as the mean \pm s.E.M.; $* P<0 \cdot 05 ; n=12$ animals/group.

The lower thyroid iodide uptake is another thyroid dysfunction caused by the lower TSH level that can impair thyroid hormone biosynthesis.

The lower liver mGPD activity, a specific tissue marker of thyroid function (Coleoni et al. 1983, Brown et al. 2002), can be explained by the hypothyroidism detected in the adult BRO group, since $\mathrm{mGPD}$ is a $\mathrm{T}_{3}$-dependent enzyme. This enzyme is responsible for transforming glycerol in dihydroxyacetone phosphate and for producing reduced equivalents to the respiratory chain, during lipolysis, and could also contribute to thermogenesis (Lardy et al. 1995, Koza et al. 1996, Bobyleva et al. 2000, dos Santos et al. 2003). So, we can suggest that the lower liver mGPD activity could be related to the hypometabolism observed in these animals (Bonomo et al. 2007).

Liver D1 activity, another $\mathrm{T}_{3}$-dependent enzyme, that is generally lower in hypothyroidism (Bianco \& Kim 2006), showed no change in BRO animals. We suggest that the unchanged D1 activity was due, at least in part, to the hyperleptinemia of these animals (Bonomo et al. 2007), since it was already described that leptin increases liver D1 activity (Cusin et al. 2000, Lisboa et al. 2003b). Therefore, the hyperleptinemia could help in maintaining this enzyme activity, despite the lower thyroid hormone levels.

The in vitro TSH release after TRH stimulation was increased in a similar way in both groups ( $\mathrm{C}$ and BRO), suggesting that the lower serum TSH is not caused by a pituitary failure in TSH synthesis and/or secretion. Then, it is possible that neonatal hypoprolactinemia programs for a hypothalamic failure in the TRH production and/or release in adult offspring. Paradoxically, pituitary D2 was lower when a higher activity was expected, since the animals were hypothyroid (Bianco \& Kim 2006). The lower pituitary D2 activity in adult $\mathrm{BRO}$ animals reinforces the hypothesis that the hypothyroidism observed in this group is associated with a possible TRH-related defect, since it was already shown that pituitary D2 is stimulated by TRH (Kim et al. 1998).

In the present study, we suggest some mechanisms induced by the maternal PRL blockage as responsible for the programming of the hypothalamus-pituitary-thyroid axis in adulthood. In general terms, programming occurs through epigenetic mechanisms, such as DNA methylation or histone acetylation, induced by neonatal stressful events (nutritional, hormonal, or environmental) and may lead to an increased risk of metabolic diseases in the adult offspring (de Moura \& Passos 2005), e.g. thyroid dysfunctions (Passos et al. 2002, Dutra et al. 2003). One of the possible imprinting factors that could act as triggering the epigenetic phenomena is the hyperleptinemia, since we already showed a higher leptin transfer and pup's hyperleptinemia at weaning in this same

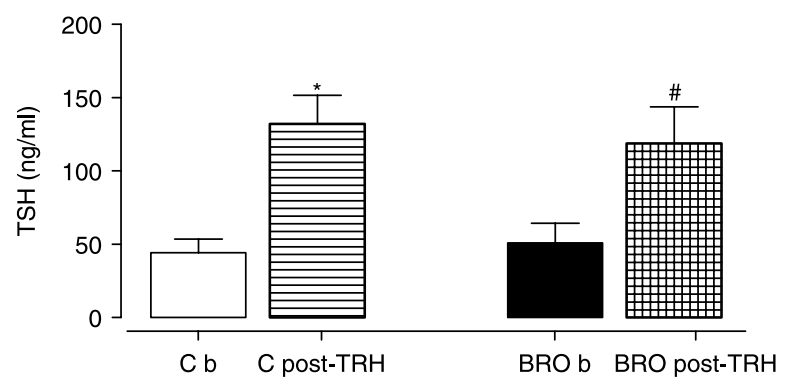

Figure 6 In vitro TSH release before and after TRH stimulation from pituitaries of 180-day-old rats whose dams were BRO treated or saline treated during 3 days of lactation. Values are given as the mean \pm S.E.M.; ${ }^{*}{ }^{*} P<0 \cdot 05 . n=12$ animals/group. 
model of PRL inhibition (Bonomo et al. 2005). Also, maternal malnutrition is associated with pup's hyperleptinemia at the end of lactation (Teixeira et al. 2002) and programs for higher serum $\mathrm{T}_{3}$ (Teixeira et al. 2003, Toste et al. 2006a). It is unlikely that BRO transferred through the milk could affect directly the PRL of the pups, since we have not detected any change in pups' PRL. Thus, these explanations may help to understand the mechanism by which the maternal hypoprolactinemia during lactation permanently change the thyroid function. Perhaps this change can turn undernourished children more susceptible to thyroid disorders in adult life (Passos et al. 2002, Dutra et al. 2003, Lisboa et al. 2008), although it deserves epidemiological and prospective studies.

So, for the first time, we demonstrated that maternal PRL inhibition by the treatment with $\mathrm{BRO}$ for a short period at the end of lactation programs for hypothyroidism in the adult offspring, which may originate from a central dysfunction, probably caused by lower TRH release. Taken together, our data provide new evidence that PRL changes during lactation play a crucial role in the regulation of body adiposity and thyroid function.

\section{Declaration of Interest}

The authors declare that there is no conflict of interest that would prejudice the impartiality of this scientific work.

\section{Funding}

This research was supported by the National Council for Scientific and Technological Development (Conselho Nacional de Desenvolvimento Científico e Tecnológico - CNPq), Coordination for the Enhancement of Higher Education Personnel (Coordenação de Aperfeiçoamento de Pessoal de Nivel Superior - CAPES), and State of Rio de Janeiro Carlos Chagas Filho Research Foundation (Fundação Carlos Chagas Filho de Amparo à Pesquisa do Estado do Rio de Janeiro - FAPERJ).

\section{Acknowledgements}

We thank Ms Mônica Moura, Mr Carlos Roberto, and Mr Luciano Santos for technical assistance.

\section{References}

Barker DJ 2004 The developmental origins of adult disease. Journal of the American College of Nutrition 23 588S-595S.

Bayne K 1996 Revised Guide for the Care and Use of Laboratory Animals available. Physiologist 39 208-211.

Bernal J, Coleoni AH \& DeGroot LJ 1978 Triiodothyronine stimulation of nuclear protein synthesis. Endocrinology 102 452-459.

Bianco AC \& Kim BW 2006 Deiodinases: implications of the local control of thyroid hormone action. Journal of Clinical Investigation 116 2571-2579.

Bobyleva V, Pazienza L, Muscatello U, Kneer N \& Lardy H 2000 Short-term hypothermia activates hepatic mitochondrial sn-glycerol-3-phosphate dehydrogenase and thermogenic systems. Archives of Biochemistry and Biophysics 380 367-372.
Bonomo IT, Lisboa PC, Passos MC, Pazos-Moura CC, Reis AM \& Moura EG 2005 Prolactin inhibition in lactating rats changes leptin transfer through the milk. Hormone and Metabolic Research 37 220-225.

Bonomo IT, Lisboa PC, Pereira AR, Passos MC \& de Moura EG 2007 Prolactin inhibition in dams during lactation programs for overweight and leptin resistance in adult offspring. Journal of Endocrinology 192 339-344.

Bradford MM 1976 A rapid and sensitive method for the quantitation of microgram quantities of protein utilizing the principle of protein-dye binding. Analytical Biochemistry 72 248-254.

Brown LJ, Koza RA, Everett C, Reitman ML, Marshall L, Fahien LA, Kozak LP \& MacDonald MJ 2002 Normal thyroid thermogenesis but reduced viability and adiposity in mice lacking the mitochondrial glycerol phosphate dehydrogenase. Journal of Biological Chemistry 277 32892-32898.

Coleoni A, Munaro N, Recupero A \& Cherubini O 1983 Nuclear triiodothyronine receptors and metabolic response in perinatally proteindeprived rats. Acta Endocrinologica 104 450-455.

Cusin I, Rouru J, Visser T, Burger AG \& Rohner-Jeanrenaud F 2000 Involvement of thyroid hormones in the effect of intracerebroventricular leptin infusion on uncoupling protein-3 expression in rat muscle. Diabetes 49 1101-1105.

Dorner G \& Plagemann A 1994 Perinatal hyperinsulinism as possible predisposing factor for diabetes mellitus, obesity and enhanced cardiovascular risk in later life. Hormone and Metabolic Research 26 213-221.

Dutra SC, Passos MC, Lisboa PC, Santos RS, Cabanelas AP, Pazos-Moura CC \& Moura EG 2003 Liver deiodinase activity is increased in adult rats whose mothers were submitted to malnutrition during lactation. Hormone and Metabolic Research 35 268-270.

Fagundes AT, Moura EG, Passos MC, Oliveira E, Toste FP, Bonomo IT, Trevenzoli IH, Garcia RM \& Lisboa PC 2007 Maternal low-protein diet during lactation programmes body composition and glucose homeostasis in the adult rat offspring. British Journal of Nutrition 25 1-7.

Fischbeck KL \& Rasmussen KM 1987 Effect of repeated reproductive cycles on maternal nutritional status, lactational performance and litter growth in ad libitum-fed and chronically food-restricted rats. Journal of Nutrition 117 1967-1975.

Fleming AS 1976 Control of food intake in the lactating rat: role of suckling and hormones. Physiology and Behavior 17 841-848.

Kajantie E, Phillips DI, Osmond C, Barker DJ, Forsen T \& Eriksson JG 2006 Spontaneous hypothyroidism in adult women is predicted by small body size at birth and during childhood. Journal of Clinical Endocrinology and Metabolism 91 4953-4956.

Kim SW, Harney JW \& Larsen PR 1998 Studies of the hormonal regulation of type $25^{\prime}$-iodothyronine deiodinase messenger ribonucleic acid in pituitary tumor cells using semiquantitative reverse transcription-polymerase chain reaction. Endocrinology 139 4895-4905.

Koza RA, Kozak UC, Brown LJ, Leiter EH, MacDonald MJ \& Kozak LP 1996 Sequence and tissue-dependent RNA expression of mouse FADlinked glycerol-3-phosphate dehydrogenase. Archives of Biochemistry and Biophysics 336 97-104.

Lardy H, Partridge B, Kneer N \& Wei Y 1995 Ergosteroids: induction of thermogenic enzymes in liver of rats treated with steroids derived from dehydroepiandrosterone. PNAS 92 6617-6619.

Legradi G, Emerson CH, Ahima RS, Flier JS \& Lechan RM 1997 Leptin prevents fasting-induced suppression of prothyrotropin-releasing hormone messenger ribonucleic acid in neurons of the hypothalamic paraventricular nucleus. Endocrinology 138 2569-2576.

Lins MC, de Moura EG, Lisboa PC, Bonomo IT \& Passos MC 2005 Effects of maternal leptin treatment during lactation on the body weight and leptin resistance of adult offspring. Regulatory Peptides 127 197-202.

Lisboa PC, Passos MC, Dutra SC, Santos RS, Bonomo IT, Cabanelas AP, Pazos-Moura CC \& Moura EG 2003a Increased 5'-iodothyronine deiodinase activity is a maternal adaptive mechanism in response to protein restriction during lactation. Journal of Endocrinology 177 261-267.

Lisboa PC, Oliveira KJ, Cabanelas A, Ortiga-Carvalho TM \& Pazos-Moura CC $2003 b$ Acute cold exposure, leptin, and somatostatin analog (octreotide) modulate thyroid 5'-deiodinase activity. American Journal of Physiology-Endocrinology and Metabolism 284 E1172-E1176. 
Lisboa PC, Passos MC, Dutra SC, Bonomo IT, Denolato AT, Reis AM \& Moura EG 2006 Leptin and prolactin, but not corticosterone, modulate body weight and thyroid function in protein-malnourished lactating rats. Hormone and Metabolic Research 38 295-299.

Lisboa PC, Fagundes ATS, Denolato ATA, Oliveira E, Bonomo IT, Alves SB, Curty FH, Passos MCF \& Moura EG 2008 Neonatal low-protein diet changes deiodinase activities and pituitary TSH response to TRH in adult rats. Experimental Biology and Medicine 233 57-63.

Lucas A 1994 Role of nutritional programming in determining adult morbidity. Archives of Disease in Childhood 71 288-290.

Miñana-Solis MC \& Escobar C 2006 Increased susceptibility to metabolic alterations in young adult females exposed to early malnutrition. International Journal of Biological Sciences 3 12-19.

Moreira RM, Lisboa PC, Curty FH \& Pazos-Moura CC 1997 Dosedependent effects of $17 \beta$-estradiol on thyrotropin releasing hormone (TRH)-induced thyrotropin (TSH) release in vitro. Brazilian Journal of Medical and Biological Research 30 1129-1134.

de Moura EG \& Passos MC 2005 Neonatal programming of body weight regulation and energetic metabolism. Bioscience Reports 25 251-269.

Moura EG, Santos CV, Moreira RM \& Pazos-Moura CC 2001 Aging and gender affect the response of thyrotropin (TSH) to gastrin releasing peptide (GRP) in rats. Life Sciences 68 1899-1904.

de Moura EG, Lisboa PC, Custodio CM, Nunes MT, de Picoli Souza K \& Passos MC 2007 Malnutrition during lactation changes growth hormone mRNA expression in offspring at weaning and in adulthood. Journal of Nutritional Biochemistry 18 134-139.

Oliveira E, Fagundes ATS, Alves SB, Pazos-Moura CC, Moura EG, Passos MCF \& Lisboa PC 2007 Chronic leptin treatment inhibits liver mitochondrial $\alpha$-glycerol-3-phosphate dehydrogenase in euthyroid rats. Hormone and Metabolic Research 39 867-870.

de Oliveira Cravo C, Teixeira CV, Passos MC, Dutra SC, de Moura EG \& Ramos C 2002 Leptin treatment during the neonatal period is associated with higher food intake and adult body weight in rats. Hormone and Metabolic Research 34 400-405.

Ortiga-Carvalho TM, Oliveira KJ, Soares BA \& Pazos-Moura CC 2002 The role of leptin in the regulation of TSH secretion in the fed state: in vivo and in vitro studies. Journal of Endocrinology 174 121-125.

Passos M, Ramos CF \& Moura EG 2000 Short and long term effects of malnutrition in rats during lactation on the body weight of offspring. Nutrition Research 20 1603-1612.

Passos MC, da Fonte Ramos C, Dutra SC, Mouco T \& de Moura EG 2002 Long-term effects of malnutrition during lactation on the thyroid function of offspring. Hormone and Metabolic Research 34 40-43.

Passos MC, Vicente LL, Lisboa PC \& de Moura EG 2004 Absence of anorectic effect to acute peripheral leptin treatment in adult rats whose mothers were malnourished during lactation. Hormone and Metabolic Research 36 625-629.

Passos MC, Lins MC, Lisboa PC, Toste FP, Bonomo IT \& de Moura EG 2007 Maternal leptin treatment during lactation programs the thyroid function of adult rats. Life Sciences $\mathbf{8 0} 1754-1758$.
Pracyk JB, Seidler FJ, McCook EC \& Slotkin TA 1992 Pituitary-thyroid axis reactivity to hyper- and hypothyroidism in the perinatal period: ontogeny of regulation of regulation and long-term programming of responses. Journal of Developmental Physiology 18 105-109.

Radetti G, Gottardi E, Bona G, Corrias A, Salardi S \& Loche S 2006 The natural history of euthyroid Hashimoto's thyroiditis in children. Journal of Pediatrics 149 827-832.

Rettori V, Pazos-Moura CC, Moura EG, Polak J \& McCann SM 1992 Role of neuromedin $\mathrm{B}$ in the control of the release of thyrotropin in hypothyroid and hyperthyroid rats. PNAS 89 3035-3039.

dos Santos R, Alfadda A, Eto K, Kadowaki T \& Silva J 2003 Evidence for a compensated thermogenic defect in transgenic mice lacking the mitochondrial glycerol-3-phosphate dehydrogenase gene. Endocrinology 144 5469-5479.

Seoane LM, Carro E, Tovar S, Casanueva FF \& Dieguez C 2000 Regulation of in vivo TSH secretion by leptin. Regulatory Peptides 92 25-29.

Silva JE 2006 Thermogenic mechanisms and their hormonal regulation. Physiological Reviews 86 435-464.

Teixeira C, Passos M, Ramos C, Dutra S \& Moura E 2002 Leptin serum concentration, food intake and body weight in rats whose mothers were exposed to malnutrition during lactation. Journal of Nutritional Biochemistry 13 493-498.

Teixeira CV, Ramos CD, Mouco T, Passos MC \& de Moura EG 2003 Leptin injection during lactation alters thyroid function in adult rats. Hormone and Metabolic Research 35 367-371.

Toste FP, Alves SB, Dutra SC, Bonomo IT, Lisboa PC, Moura EG \& Passos MC 2006 a Temporal evaluation of the thyroid function of rats programed by leptin treatment on the neonatal period. Hormone and Metabolic Research 38 827-831.

Toste FP, de Moura EG, Lisboa PC, Fagundes AT, de Oliveira E \& Passos MC $2006 b$ Neonatal leptin treatment programmes leptin hypothalamic resistance and intermediary metabolic parameters in adult rats. British Journal of Nutrition 95 830-837.

Veiga MA, Oliveira KJ, Curty FH \& Pazos-Moura CC 2004 Thyroid hormones modulate the endocrine and autocrine/paracrine action of letpin on thyrotropin secretion. Journal of Endocrinology 183 243-247.

Vicente LL, de Moura EG, Lisboa PC, Monte Alto Costa A, Amadeu T, Mandarim-de-Lacerda CA \& Passos MC 2004 Malnutrition during lactation in rats is associated with higher expression of leptin receptor in the pituitary of adult offspring. Nutrition 20 924-928.

Walker P \& Courtin F 1985 Transient neonatal hyperthyroidism results in hypothyroidism in the adult rat. Endocrinology 116 2246-2250.

Received in final form 27 April 2008

Accepted 19 May 2008

Made available online as an Accepted Preprint

19 May 2008 